\title{
Orphanin-FQ/Nociceptin (OFQ/N) Modulates the Activity of Suprachiasmatic Nucleus Neurons
}

\author{
Charles N. Allen, ${ }^{1,2}$ Zhi-Gen Jiang, ${ }^{1}$ Koji Teshima, ${ }^{1}$ Tristan Darland, ${ }^{3}$ Masayuki Ikeda, ${ }^{5}$ Cole S. Nelson, ${ }^{1}$ \\ Denise I. Quigley, ${ }^{4}$ Tohru Yoshioka, ${ }^{5}$ Richard G. Allen, ${ }^{1}$ Michael A. Rea, ${ }^{6}$ and David K. Grandy ${ }^{2,3}$ \\ ${ }^{1}$ Center for Research on Occupational and Environmental Toxicology and Departments of 2Physiology and Pharmacology, \\ ${ }^{3} \mathrm{Cell}$ and Developmental Biology, and 4 Molecular and Medical Genetics, Oregon Health Sciences University, Portland, \\ Oregon 97201-3098, 5Department of Molecular Neurobiology, School of Human Sciences, Waseda University, Mikajima, \\ Tokorozawa, Saitama 359, Japan, and ${ }^{6}$ Biological Rhythms and Integrative Neurosciences Research Institute, Air Force \\ Research Laboratory, Brooks Air Force Base, Texas 78235
}

Neurons in the suprachiasmatic nucleus (SCN) constitute the principal circadian pacemaker of mammals. In situ hybridization studies revealed expression of orphanin-FQ/nociceptin (OFQ/N) receptor (NOR) mRNA in the SCN, whereas no expression of mRNA for preproOFQ/N (ppOFQ/N) was detected. The presence of OFQ/N peptide in the SCN was demonstrated by radioimmunoassay. SCN neurons (88\%) responded dosedependently to OFQ/N with an outward current $\left(\mathrm{EC}_{50}=22.3\right.$ $\mathrm{nm}$ ) that was reduced in amplitude by membrane hyperpolarization and reversed polarity near the theoretical potassium equilibrium potential. [Phe ${ }^{1} \psi\left(\mathrm{Ch}_{2}-\mathrm{NH}\right) \mathrm{Gly}{ }^{2}$ ]OFQ/N(1-13) $\mathrm{NH}_{2}(3$ $\mu \mathrm{M})$, a putative NOR antagonist, activated a small outward current and significantly reduced the amplitude of the OFQ/N- stimulated current. OFQ/N reduced the NMDA receptormediated increase in intracellular $\mathrm{Ca}^{2+}$. When injected unilaterally into the SCN of Syrian hamsters housed in constant darkness, OFQ/N (1-50 pmol) failed to alter the timing of the hamsters' wheel-running activity. However, injection of OFQ/N (0.1-50 pmol) before a brief exposure to light during the midsubjective night significantly attenuated the light-induced phase advances of the activity rhythm. These data are consistent with the interpretation that OFQ/N acting at specific receptors modulates the activity of SCN neurons and, thereby, the response of the circadian clock to light.

Key words: orphanin-FQ; nociceptin; suprachiasmatic nucleus; circadian rhythm; potassium current; calcium
Organisms display regular, daily fluctuations in behavioral and physiological processes called circadian rhythms. In mammals, the principal pacemaker of circadian rhythms is located in the suprachiasmatic nucleus (SCN), a paired structure lying dorsal to the optic chiasm in the ventral hypothalamus (Meijer and Rietveld, 1989). SCN-driven circadian rhythms are synchronized to the environmental light/dark (LD) cycle via a process called "photic entrainment," whereby the phase and period of the circadian clock are adjusted by exposure to ambient light, maintaining the proper phase relationships between circadian rhythms and relevant daily environmental changes (DeCoursey, 1964; Morin, 1994). Photic information is transmitted directly to the SCN via the glutamatergic retinohypothalamic tract (RHT) (De Vries et al., 1993; Morin, 1994; Moore et al., 1995). Neurons in the retina project directly to the SCN, use glutamate as a neurotransmitter, and activate NMDA and AMPA receptors (Kim and Dudek, 1991; Rea et al., 1993; Jiang et al., 1997). Activation of NMDA receptors can phase advance or phase delay the biological clock depending on the circadian time of application (Ding et al., 1994; Shirakawa and Moore, 1994). A signaling pathway has been

\footnotetext{
Received Oct. 13, 1998; revised Dec. 14, 1998; accepted Dec. 22, 1998.

The work was supported by National Institutes of Health Grants AG10794, NS036607 (C.N.A.), and DA08562 (D.K.G.), by Air Force Office of Scientific Research Grant 96-AL-004 (M.A.R.), and by the "Research for the Future" Program 96L00310 from the Japan Society for the Promotion of Science. We would like to thank Matthew J. Cato for providing excellent technical assistance.

Correspondence should be addressed to Dr. Charles N. Allen, Center for Research on Occupational and Environmental Toxicology, L606, Oregon Health Sciences University, 3181 Southwest Sam Jackson Park Road, Portland, OR 972013098.

Copyright (C) 1999 Society for Neuroscience $\quad 0270-6474 / 99 / 192152-09 \$ 05.00 / 0$
}

proposed in which activation of NMDA receptors increases intracellular $\mathrm{Ca}^{2+}$, which in turn activates nitric oxide synthase and increases nitric oxide that, via steps involving the activation of protein kinase $\mathrm{G}$ and ryanodine receptors, alters the timing of the circadian clock (Ding et al., 1994, 1998; Weber et al., 1995a,b).

The SCN contains a number of peptide neurotransmitters including vasopressin, vasoactive intestinal peptide (VIP), and neuropeptide Y (Van den Pol and Tsujimoto, 1985). These peptides are believed to be important regulators of SCN neuronal activity and the phase of the circadian clock (Inouye, 1996). Recently a G-protein-coupled receptor that is $65 \%$ identical to the $\mu-, \delta$-, and $\kappa$-opioid receptors was discovered. This orphan receptor shows no high-affinity binding to selective opioid agonists or antagonists (Bunzow et al., 1994; Mollereau et al., 1994). The endogenous ligand for this receptor is a heptadecapeptide (FGGFTGARKSARKLANQ) that resembles dynorphin and was named both orphanin-FQ (Reinscheid et al., 1995) and nociceptin (Meunier et al., 1995) (OFQ/N). Synthetic ${ }^{125} \mathrm{I}-\mathrm{OFQ} / \mathrm{N}$, which has a low affinity for the $\mu-, \delta$-, and $\kappa$-opioid receptors, binds the $\mathrm{OFQ} / \mathrm{N}$ receptor (NOR) in a saturable and specific manner that is insensitive to the opioid antagonist naloxone (Mollereau et al., 1996; Nothacker et al., 1996). OFQ/ $\mathrm{N}$ is synthesized as part of a precursor protein, preproOFQ/N (ppOFQ/ $\mathrm{N}$ ), whose organization is similar to that of pro-opiomelanocortin, preproenkephalin, and preprodynorphin (Mollereau et al., 1996; Nothacker et al., 1996). In the course of an in situ hybridization survey of the rat hypothalamus, we discovered that NOR was densely expressed in the SCN. Because of the presence of NOR in the $\mathrm{SCN}$, we performed experiments to determine whether 
OFQ/N can modulate the activity of SCN neurons and alter the timing of the circadian clock.

\section{MATERIALS AND METHODS}

In situ hybridization. In situ hybridization was performed using sense and antisense ${ }^{35} \mathrm{~S}-\mathrm{UTP}-$ labeled riboprobes corresponding to the first 100 $\mathrm{N}$-terminal amino acids of NOR that has low homology to the $\mu-, \delta$-, and $\kappa$-opioid receptors (Bunzow et al., 1994). For detection of ppOFQ/N, a nearly full-length $\mathrm{OFQ} / \mathrm{N}$ clone was prepared by reverse transcriptase PCR using oligonucleotide primers. The cDNA used to make the riboprobe was sequenced and found to be identical to the published sequence (Meunier et al., 1995). Riboprobes were purified on Sephadex G-50 columns (Pharmacia, Piscataway, NJ) and diluted to a final concentration of $2 \times 10^{6} \mathrm{cpm} / \mathrm{ml}$ in a hybridization solution consisting of $500 \mu \mathrm{g} / \mathrm{ml}$ tRNA, $50 \mu \mathrm{M}$ dithiothreitol (DTT), $50 \%$ formamide, $0.25 \mathrm{~mm} \mathrm{NaCl}, 1 \times$ Denhardt's solution, and 10\% dextran sulfate. Adult male Sprague Dawley rats were anesthetized with isoflurane and perfused with $4 \%$ paraformaldehyde dissolved in borate buffer, $\mathrm{pH}$ 9.5. The brain was dissected out and incubated overnight in fix plus $20 \%$ sucrose. Twenty-micrometerthick sections were cut on a cryostat and mounted onto Superfrost Plus slides (VWR, San Francisco, CA). The slides were fixed in $4 \%$ paraformaldehyde dissolved in PBS, permeabilized with proteinase $\mathrm{K}$, acetylated in acetic anhydride and triethanolamine, and dehydrated in ethanol. The probe-containing solution was placed on the slides and incubated overnight. The slides were rinsed with $4 \times$ SSC, RNase treated $\left(25 \mu \mathrm{g} / \mathrm{ml} \mathrm{RNase} \mathrm{A}\right.$ for $30 \mathrm{~min}$ at $\left.37^{\circ} \mathrm{C}\right)$, rinsed in decreasing concentrations of SSC containing $1 \mathrm{~mm}$ DTT (final stringency at $0.1 \times$ and $70^{\circ} \mathrm{C}$ ), and dehydrated in ascending concentrations of ethanol. The slides were exposed to $\beta$-max film for $2-3 \mathrm{~d}$ before being dipped in NBT- 2 emulsion (Kodak, Rochester, NY). After 2 weeks of exposure at $4^{\circ} \mathrm{C}$, the slides were developed in D-19 developer (Kodak) and counterstained with thionin. Alternating slides were used to conduct the same survey with a sense riboprobe and with thionin staining alone. The sections were mounted on glass slides, exposed to Cronex film (Dupont, Billerica, DE) for $5 \mathrm{~d}$, dipped in emulsion, and exposed for 2 weeks.

Preparation of SCN brain slices. Male Sprague Dawley rats (200-300 gm) were maintained on a light/dark schedule of $12 \mathrm{hr}$ light and $12 \mathrm{hr}$ dark (LD 12:12; lights on at 8:00 A.M.) for at least 2 weeks. During the lights-on phase, rats were deeply anesthetized with halothane, and their brains were removed and placed in ice-cold Krebs' solution consisting of (in mM): $\mathrm{NaCl}, 126 ; \mathrm{KCl}, 2.5 ; \mathrm{NaH}_{2} \mathrm{PO}_{4}, 1.2 ; \mathrm{MgCl}_{2}, 1.2 ; \mathrm{CaCl}_{2}, 2.4$; glucose, 11; and $\mathrm{NaHCO}_{3}, 26$, saturated with $95 \% \mathrm{O}_{2} / 5 \% \mathrm{CO}_{2}$. Horizontal $(500-\mu \mathrm{m}$-thick) or coronal (300- $\mu \mathrm{m}$-thick) slices of hypothalamus were cut with a vibratome. The horizontal slices were secured in the recording chamber and completely immersed in continuously flowing, warmed $\left(36^{\circ} \mathrm{C}\right) \mathrm{Krebs}$ s solution with the $\mathrm{NaHCO}_{3}$ reduced to $20 \mathrm{~mm}, \mathrm{pH}$ 7.4. The SCN was identified in the slice, by the use of a stereomicroscope, as the gray matter region immediately dorsal to the optic chiasm and within $500 \mathrm{~mm}$ of the midline. Additional experiments were performed with the SCN visualized using infrared differential interference videomicroscopy (IR-DIC) (Dodt and Zieglgänsberger, 1990). Coronal slices $(300 \mu \mathrm{m})$ were mounted on the stage of a Optiphot-2 microscope (Nikon, Tokyo, Japan) and visualized with an IR-CCD camera and camera controller (Hamamatsu Photonics, Hamamatsu City, Japan). The University Animal Care Committee approved all procedures involving animals.

Patch clamp recording. Recordings were made using the whole cell and perforated patch-clamp modes from 0.5 to $12 \mathrm{hr}$ after preparation of the slices. Whole-cell patch electrodes had outside tip diameters of $\sim 1 \mu \mathrm{m}$ and resistances of $\sim 5 \mathrm{M} \Omega$ when filled with a solution containing (in $\mathrm{mM}$ ): $\mathrm{K}^{+}$gluconate, $125 ; \mathrm{NaCl}, 15 ; \mathrm{CaCl}_{2}, 1 ; \mathrm{MgCl}_{2}, 2$; HEPES, 10; EGTA, 11; ATP, 3; and GTP, 0.3 , at pH 7.3. The electrode was advanced into the brain slice, and a seal with the cell membrane was obtained by applying negative pressure. Seal resistances ranged from 5 to $20 \mathrm{G} \Omega$. The membrane was ruptured by further negative pressure, producing intracellular access with series resistances of 8-20 M $\Omega$. Membrane potentials or currents were measured with an Axopatch-1D amplifier (Axon Instruments, Foster City, CA) and recorded on a pen recorder and an on-line personal computer (IBM AT) equipped with pClamp 5.0 (Axon Instruments).

Additional experiments were performed using the nystatin perforated patch technique (Akaike and Harata, 1994). Nystatin was dissolved in methanol $(10 \mathrm{mg} / \mathrm{ml})$ and then diluted just before recording to a final concentration of $150-300 \mu \mathrm{g} / \mathrm{ml}$ in an electrode-filling solution consisting of $150 \mathrm{~mm} \mathrm{KCl}$ and $10 \mathrm{~mm}$ HEPES, at $\mathrm{pH}$ 7.2. Microelectrodes with resistances of 6-10 M $\Omega$ were pulled from borosilicate glass (WPI) and polished with a microforge (Narishige, Tokyo, Japan). Recording began 10-15 min after formation of a $G \Omega$ seal when the series resistance stabilized between 30 and $50 \mathrm{M} \Omega$. The data were recorded with a Axopatch 200A amplifier (Axon Instruments) and an on-line Macintosh G3 computer using Pulse and PulseFit (HEKA).

OFQ/N (300 nM) was ejected by pressure (2-3 psi) through a micropipette (with tip diameters of $\sim 2 \mu \mathrm{m}$ and locations 30-50 $\mu \mathrm{m}$ away from the cell body) with a Picospritzer (General Valve, Fairfield, NJ) under computer control. OFQ/N antagonist and naloxone were applied by bath perfusion. Bicuculline $(10 \mu \mathrm{M})$ and tetrodotoxin $(1 \mu \mathrm{M})$ were routinely added to the medium to suppress spontaneous inhibitory synaptic currents and sodium currents.

Calcium imaging. Coronal slices $(210 \mu \mathrm{m})$ of the hypothalamus were prepared from 3- to 4-week-old C57B1/6J black mice. The slices were incubated for $1 \mathrm{hr}$ in a Krebs' solution containing (in $\mathrm{mM}$ ): $\mathrm{NaCl}, 138.6$; $\mathrm{KCl}, 3.35 ; \mathrm{NaHCO}_{3}, 21 ; \mathrm{NaH}_{2} \mathrm{PO}_{4} \cdot \mathrm{H}_{2} 0,9.9$; D-glucose, 9.9, and $\mathrm{CaCl}_{2}$, 2.5; and $\mathrm{MgCl}_{2}$, 1 , continuously bubbled with $95 \% \mathrm{O}_{2} / 5 \% \mathrm{CO}_{2}$. The slices were incubated for $1 \mathrm{hr}$ in $10 \mu \mathrm{M}$ fura-2 AM (Molecular Probes, Eugene, OR) with $0.001 \%$ cremophore EL (Sigma, St. Louis, MO). The slices were then incubated in the Krebs' media for at least 30 min, then transferred to the stage of an Axioplan 2 microscope (Zeiss, Thornwood, NY) equipped with a $10 \times$ water-immersion objective (Olympus, Melville, NY), and perfused at $1.5 \mathrm{ml} / \mathrm{min}$ with Krebs' solution. Changes in intracellular $\mathrm{Ca}^{2+}$ were estimated from the ratio of emission intensities excited by consecutive pulses of light with wavelengths of 340 and 380 $\mathrm{nm}$. The images were projected onto a cooled CCD camera (C4880; Hamamatsu Photonics) that was designed for real time imaging of intracellular $\mathrm{Ca}^{2+}$ levels. Data analysis was performed on-line by an Argus CA50 computer-based software system (Hamamatsu Photonics). All techniques were performed at room temperature.

Effects of $O F Q / N$ on circadian phase. Adult male Syrian hamsters (Mesocricetus auratus) obtained from Charles River Laboratories (Wilmington, MA) were maintained in our animal facility under LD 14:10 for at least 2 weeks before experimentation. Under general anesthesia (ketamine at $12.5 \mathrm{mg} / \mathrm{kg}$, xylazine at $20 \mathrm{mg} / \mathrm{kg}$, and acepromazine maleate at $2 \mathrm{mg} / \mathrm{kg}$ ), hamsters (130-160 gm) received intracranial cannula guides (26 ga) stereotaxically aimed at the SCN $(0.8 \mathrm{~mm}$ anterior to bregma, 1.6 $\mathrm{mm}$ lateral to the midline, and $2.9 \mathrm{~mm}$ below the dura, at an angle of $10^{\circ}$ from the sagittal plane). Cannula guides were secured in place with machine screws and dental cement. After at least 1 week in LD 14:10 to recover from the surgery, animals were transferred to individual cages equipped with a running wheel and were maintained under constant darkness for the remainder of the experiment.

Wheel-running activity was monitored continuously by an Intel 486based computer running Dataquest III data acquisition software (Minimitter, Sunriver, OR) as described elsewhere (Rea et al., 1993). The onset of wheel-running activity, designated as circadian time 12 (CT12), was used as a phase reference point for the timing of drug administration and light exposure. CT12 on the day of treatment was estimated by extrapolation of the regression line fitted to activity onsets on the $5 \mathrm{~d}$ before treatment. Phase shifts of the free-running activity rhythm were estimated by comparing this value with the value for CT12 obtained after back extrapolation of the regression line fitted through activity onsets on post-treatment days 4-9 to the day of treatment (Rea et al., 1993).

After stable free-running activity rhythms were established (8-14 d), animals were removed from their cages in darkness using an infrared viewer. At specific times relative to activity onset (CT12), hamsters received intra-SCN injections $(0.3 \mu \mathrm{l})$ of either vehicle $[0.01 \%$ bovine serum albumin in a solution of (in $\mathrm{mM}$ ): $\mathrm{NaCl}, 122 ; \mathrm{KCl}, 3.8 ; \mathrm{MgSO}_{4}, 1.2$; $\mathrm{KH}_{2} \mathrm{PO}_{4}, 1.2 ; \mathrm{NaHCO}_{3}, 25$; and $\left.\mathrm{CaCl}_{2}, 1.2\right]$ or 50 pmol of synthetic $\mathrm{OFQ} / \mathrm{N}$. Administration was achieved using a 33 ga infusion cannula attached to a $1 \mu$ l Hamilton syringe (Rea et al., 1993). The infusion cannula extended $4.4 \mathrm{~mm}$ beyond the tip of the guide, to a position near the dorsolateral border of the right SCN. In a separate experiment, hamsters received intra-SCN injections $(0.3 \mu \mathrm{l})$ of either vehicle or a single dose $(0.1-50 \mathrm{pmol})$ of synthetic $\mathrm{OFQ} / \mathrm{N}$ given $10 \mathrm{~min}$ before a brief light exposure (20 lux for $10 \mathrm{~min}$ ). Injections were timed so that light exposure occurred $7 \mathrm{hr}$ after the predicted activity onset (CT19). After treatment, the hamsters were returned to darkness, and wheel-running activity was monitored for an additional 10-14 d. After data collection, the location of the injection site was verified histologically by examining $100-\mu \mathrm{m}$-thick vibratome sections cut through the injection site. Data were analyzed by one-way ANOVA, and differences between means were 

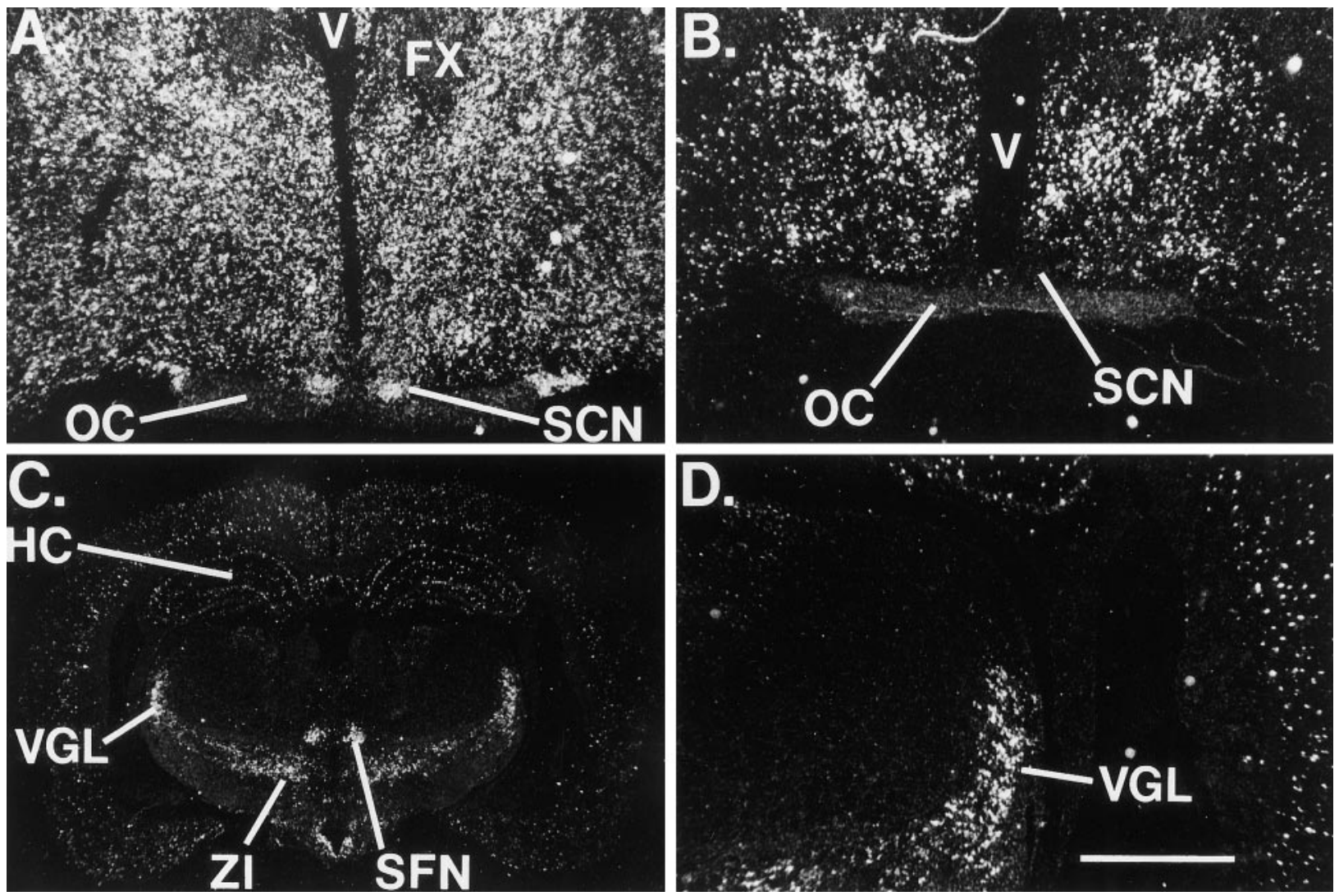

Figure 1. A, Distribution of NOR mRNA in the rat brain. Dark-field illumination of a coronal section through the level of the $S C N$ shows dense staining within the $S C N$. $B-D$, Expression of preproOFQ/N mRNA. $B$, Lack of expression in the $S C N$. $C$, PreproOFQ/N staining in the $V G L, Z I$, and $S F N$. $D$, The hybridization signal in the $V G L$ in the same section shown in $C$. No signal was observed when a sense probe was used. Scale bar: $A, B, D, 400 \mu \mathrm{m}$; $C, 173 \mu \mathrm{m}$. $H C$, Hippocampus; $O C$, optic chiasm; $S C N$, suprachiasmatic nucleus; $S F N$, subparafasicular nucleus; $V$, third ventricle; $V G L$, ventral lateral geniculate nucleus; ZI, zona incerta; FX, fornix.

tested post hoc for significance $(p<0.05)$ using the Student's NewmanKeuls test.

OFQ/N radioimmunoassay. Synthetic OFQ/N peptide (Phoenix Pharmaceuticals, Mountain View, CA) was coupled in a 10:1 ratio to bovine serum albumin using the carbodiimide method and was sent to a commercial vendor for rabbit immunization (Covance, Princeton, NJ). $\mathrm{Tyr}_{14} \mathrm{OFQ} / \mathrm{N}$ was iodinated using the chloramine $\mathrm{T}$ method and fractionated over a G-10 column in $10 \%$ acetic acid; the peak of radioactivity was collected and diluted with deionized water containing $30 \mu \mathrm{m}$ of Aprotinin (Sigma). Coronal brain slices $(400 \mu \mathrm{m})$ were prepared as described above. The SCNs were punched out using a 16 ga needle and stored at $-80^{\circ} \mathrm{C}$. The SCNs from six rats were pooled for the radioimmunoassay (RIA). The punches were homogenized in $10 \%$ acetic acid containing $0.5 \mathrm{mg} / \mathrm{ml}$ bovine serum albumin and $3 \mathrm{~mm}$ phenylmethylsulfonyl fluoride, frozen and thawed three times, and centrifuged; and the resulting supernatants were frozen and lyophilized. Before the RIA, the samples were resuspended in phosphate buffer containing $\beta$-mercaptoethanol and bovine serum albumin as described previously (Quigley et al., 1998).

\section{RESULTS}

\section{Localization of OFQ/N peptide and receptors in the SCN}

In the course of our efforts to identify G-protein-coupled receptors that may modulate the firing of SCN neurons, we examined the expression of NOR in the SCN of adult rats by in situ hybridization. A radiolabeled riboprobe complimentary to the first 100 nucleotides of NOR revealed considerable mRNA expression throughout the hypothalamus and the SCN (Fig. 1A). To assess whether OFQ/N peptide was present in the $\mathrm{SCN}$, a quan- titative OFQ/N-specific RIA was used. This sensitive assay detected $3.25 \mathrm{pmol} / \mathrm{gm}$ of the tissue wet weight (mean). This value is similar to $3.21 \mathrm{pmol} / \mathrm{gm}$ reported previously for the determination of OFQ/N in the rat hypothalamus (Quigley et al., 1998). These data demonstrate that the OFQ/N peptide and NOR are present in the SCN.

SCN neurons synthesize several neurotransmitters including vasopressin and VIP. Because OFQ/N was detected in the SCN by RIA, it was of interest to determine whether these neurons expressed ppOFQ/N mRNA. For this analysis, in situ hybridization studies were performed on serial sections of adult male rat brain using a radiolabeled rat riboprobe. The $\mathrm{ppOFQ} / \mathrm{N}$ probe revealed the presence of its mRNA in the zona incerta $(\mathrm{ZI})$, the CA1 and CA3 pyramidal cells of the hippocampus, the granule cells of the dentate gyrus, and cells in the ventral lateral geniculate nucleus (VGL) (Fig. 1C,D). However, four attempts failed to detect ppOFQ/N mRNA in the SCN (Fig. $1 B$ ), suggesting that $\mathrm{OFQ} / \mathrm{N}$ and NOR are present in the $\mathrm{SCN}$ but that ppOFQ/N is synthesized elsewhere in the brain.

\section{Electrophysiological responses of SCN neurons to OFQ/N}

The abundance of NOR mRNA and OFQ/N peptide in the SCN suggested that activation of NORs would alter the activity of SCN neurons. To explore this possibility, we applied OFQ/N by bath superfusion or from a micropipette to SCN neurons maintained in brain slices. In $88 \%$ (45 of 51) of the SCN neurons examined, 


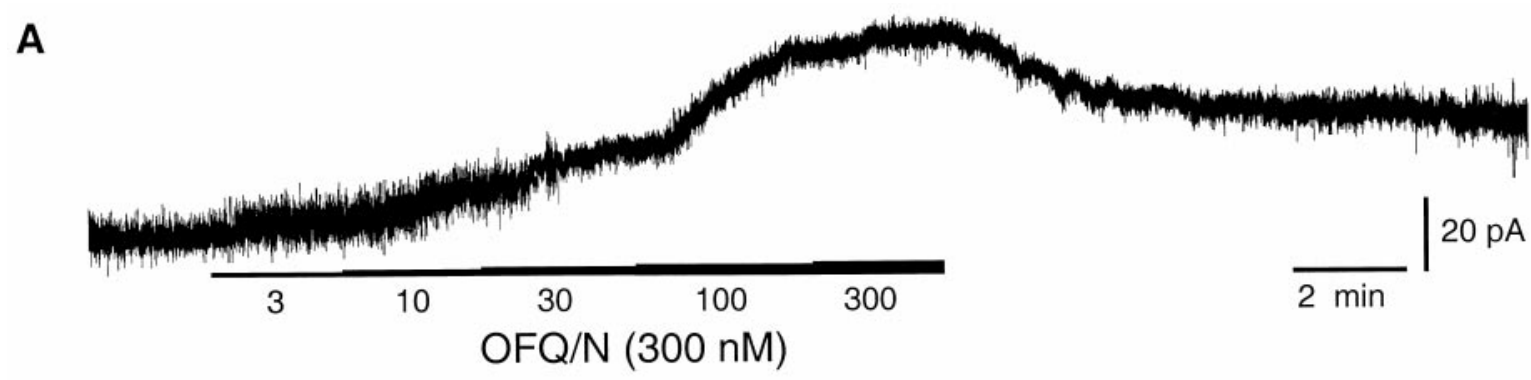

B

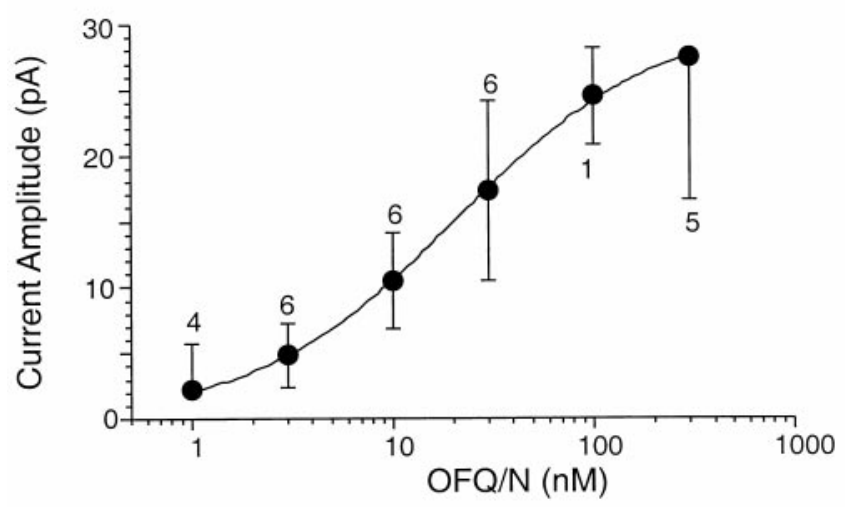

C

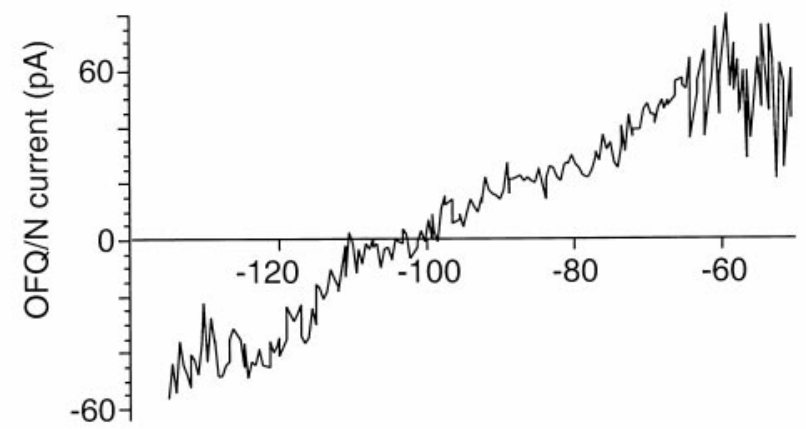

Membrane Potential (mV)

Figure 2. $\mathrm{OFQ} / \mathrm{N}$ activated a current in $\mathrm{SCN}$ neurons. $A, \mathrm{OFQ} / \mathrm{N}$ induced an outward current when applied to an $\mathrm{SCN}$ neuron voltage-clamped at -60 $\mathrm{mV}$. Note that the amplitude of the current was larger with increasing concentrations of OFQ/N (3-300 nM). B, Concentration-effect curve for $\mathrm{OFQ} / \mathrm{N}$-activated currents is shown. The $\mathrm{EC}_{50}$ was estimated to be $22.3 \mathrm{nM}$. The numerals above and below the SEM bars indicate the number of cells recorded at each $\mathrm{OFQ} / \mathrm{N}$ concentration. $\mathrm{C}$, Reversal potential of $\mathrm{OFQ} / \mathrm{N}$-induced current.

$\mathrm{OFQ} / \mathrm{N}$ dose-dependently $\left(\mathrm{EC}_{50}=22.3 \mathrm{nM}\right)$ activated a robust outward current that reached an average of $22.1 \pm 4 \mathrm{pA}(n=11$; mean $\pm \mathrm{SEM})$ at a peptide concentration of $100 \mathrm{~nm}$ (Fig. $2 A, B)$. The amplitude of the OFQ/N-induced current in SCN neurons was found to be increased by membrane potential depolarization and decreased by hyperpolarization and was always associated with an increase in input conductance $(0.51 \pm 0.1 \mathrm{nS})$.

To determine the ionic nature of the current induced by OFQ/N, we identified the potential at which it reversed polarity. The OFQ/N-induced current reversed between -95 and -112 $\mathrm{mV}\left[\right.$ mean $=-103 \mathrm{mV}(n=3)$ at $\left[\mathrm{K}^{+}\right]_{\mathrm{o}}=2.5 \mathrm{~mm}$; Fig. $\left.2 C\right]$. This current was sensitive to changes in the extracellular $\mathrm{K}^{+}$concentration. Raising the $\left[\mathrm{K}^{+}\right]_{\mathrm{o}}$ to $10 \mathrm{~mm}$ shifted the reversal potential of the OFQ/N-induced current to -69 and $-74 \mathrm{mV}(n=2)$.

The putative NOR antagonist $\left[\mathrm{Phe}^{1} \psi\left(\mathrm{CH}_{2}-\mathrm{NH}\right) \mathrm{Gly}^{2}\right] \mathrm{OFQ} /$ $\mathrm{N}(1-13) \mathrm{NH}_{2}$ was used to determine whether the OFQ/Nactivated current was mediated by its receptor or by one of the classical opioid receptors. In these experiments, $300 \mathrm{~nm} \mathrm{OFQ/N}$ was pressure applied to SCN neurons for $2 \mathrm{sec}$, and recordings were made using the nystatin perforated patch technique. Bath application of the putative OFQ/N antagonist $(3 \mu \mathrm{M})$ resulted in a $70 \%$ inhibition of the OFQ/N-activated current $(11.5 \pm 2.2$ vs $3.5 \pm 0.9 \mathrm{pA}$; mean $\pm \mathrm{SE} ; n=5$; Fig. 3 ). In contrast, naloxone had no effect on the amplitude of OFQ/N-activated currents $(10.4 \pm$ 2.1 vs $10.9 \pm 0.8 \mathrm{pA} ; n=3$; Fig. 3). Application of the putative OFQ/N antagonist $(3 \mu \mathrm{M})$ alone produced a small outward current (4.6-20.6 pA; six of nine cells), suggesting that $\left[\mathrm{Phe}^{1} \psi\left(\mathrm{CH}_{2}-\right.\right.$ $\mathrm{NH}) \mathrm{Gly}^{2}$ ]OFQ/N(1-13) $\mathrm{NH}_{2}$ has both agonist and antagonist activity at NOR. Multiple applications of OFQ/N (300 nM; $2 \mathrm{sec})$ at 1 min intervals continued to activate additional outward current. This demonstrates that the currents activated by OFQ/N antagonist application did not reduce the amplitude of OFQ/Nactivated currents by maximally stimulating the OFQ/Nactivated currents. Therefore, the block of the OFQ/N-activated current by $\left[\mathrm{Phe}^{1} \psi\left(\mathrm{CH}_{2}-\mathrm{NH}\right) \mathrm{Gly}^{2}\right] \mathrm{OFQ} / \mathrm{N}(1-13) \mathrm{NH}_{2}$ was not caused by a saturation of NOR stimulation. These data demonstrate that $\mathrm{OFQ} / \mathrm{N}$ activates a $\mathrm{K}^{+}$current in $\mathrm{SCN}$ neurons via a unique receptor that is not a member of the naloxone-sensitive opioid receptor family. In addition, [ $\left.\mathrm{Phe}^{1} \psi\left(\mathrm{CH}_{2}-\mathrm{NH}\right) \mathrm{Gly}^{2}\right] \mathrm{OFQ} /$ $\mathrm{N}(1-13) \mathrm{NH}_{2}$ is a partial agonist of NOR in the SCN with actions similar to those observed in the spinal cord (Xu et al., 1998).

\section{Effect of OFQ/N on circadian phase}

Because both OFQ/N immunoreactivity and its receptor mRNA were detected in the SCN and OFQ/N activated a robust $\mathrm{K}^{+}$ current in the slice preparation, we sought to determine whether $\mathrm{OFQ} / \mathrm{N}$ was capable of altering the phase of the circadian clock in vivo. OFQ/N (50 pmol) or vehicle was injected into the SCN region of free-running Syrian hamsters maintained in constant darkness. Groups of hamsters received injections at four different circadian times: CT2 (10 hr before anticipated activity onset), CT8 (4 hr before anticipated activity onset), CT14 (2 hr after anticipated activity onset), and CT20 (8 hr after anticipated activity onset). In all cases, OFQ/ $\mathrm{N}$ injection failed to alter significantly circadian phase [phase shifts, CT2, $5.7 \pm 4.5 \mathrm{~min}$ $(n=6) ; \mathrm{CT} 8,6.0 \pm 14.4 \min (n=4) ; \mathrm{CT} 14,8.0 \pm 5.1 \mathrm{~min}(n=$ 6); and CT20, $2 \pm 10.9 \min (n=6)]$. These effects of OFQ/N 


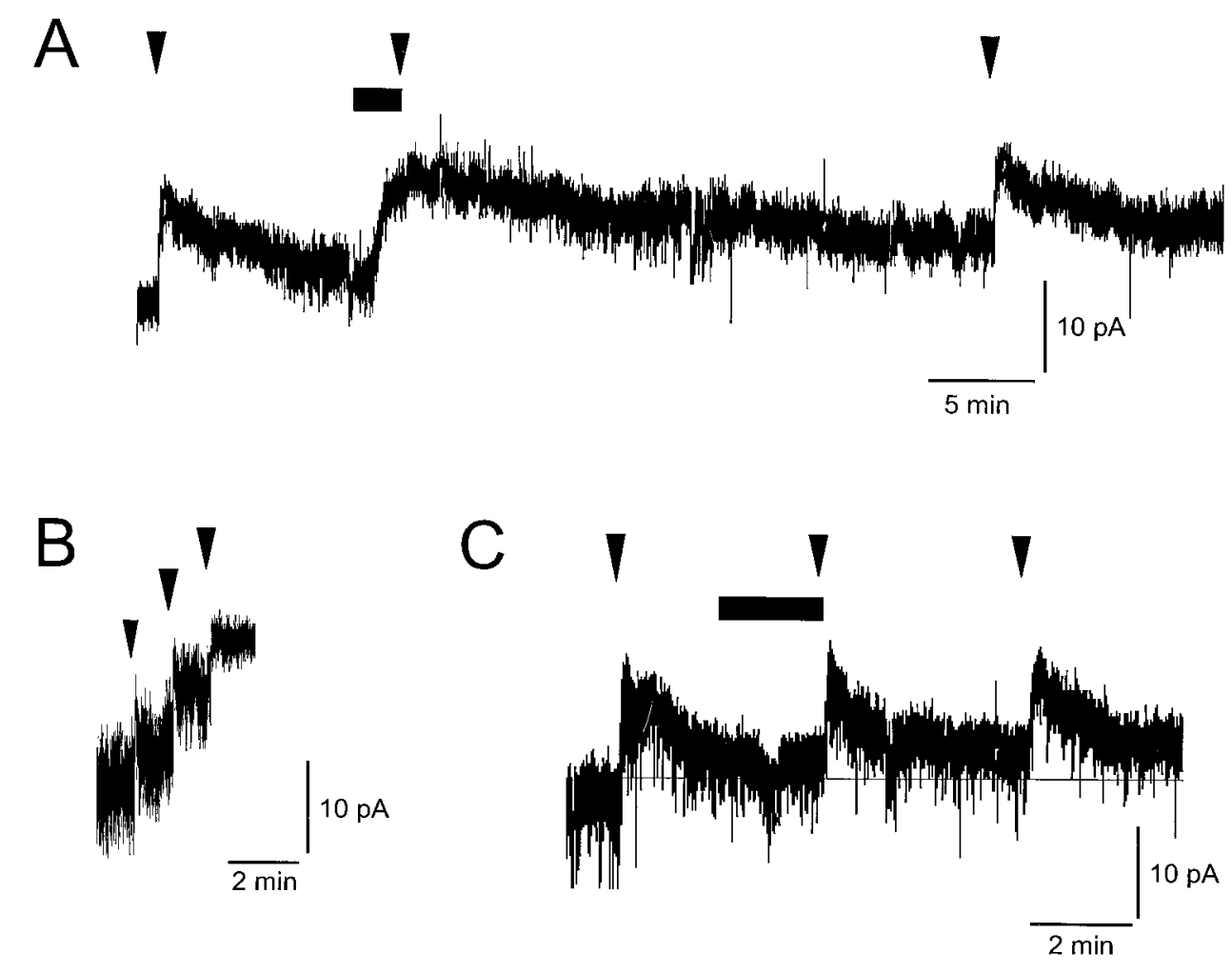

Figure 3. Effects of $\left[\mathrm{Phe}^{1} \psi\left(\mathrm{CH}_{2}-\right.\right.$ $\mathrm{NH}) \mathrm{Gly}^{2}$ OFQ/N(1-13) $\mathrm{NH}_{2}$ and naloxone on OFQ $/ \mathrm{N}$-activated currents. $A$, Currents activated by a $2 \mathrm{sec}$ application of $\mathrm{OFQ} / \mathrm{N}(300 \mathrm{nM}$; arrowheads $)$ are

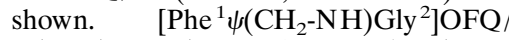
$\mathrm{N}(1-13) \mathrm{NH}_{2}(3 \mu \mathrm{M}$; horizontal bar $)$ was bath applied. Note that the OFQ/N antagonist activated an outward current and the subsequent application of $\mathrm{OFQ} / \mathrm{N}$ did not activate an additional current. These data suggest that the $\mathrm{OFQ} / \mathrm{N}$ antagonist has both agonist and antagonist activity at NOR. $B$, Multiple application of OFQ/N (300 nM; 2 sec; arrowheads) continued to activate additional current. This demonstrates that the OFQ/N $(300 \mathrm{~nm} ; 2 \mathrm{sec})$ application did not saturate the potential $\mathrm{OFQ} / \mathrm{N}$-activated currents. Therefore, the block of the $\mathrm{OFQ} / \mathrm{N}$-activated current by $\quad\left[\mathrm{Phe}^{1} \psi\left(\mathrm{CH}_{2}-\mathrm{NH}\right) \mathrm{Gly}^{2}\right] \mathrm{OFQ} / \mathrm{N}(1-$ 13) $\mathrm{NH}_{2}$ was not attributable to a saturation of NOR stimulation. $C$, Naloxone (1 $\mu \mathrm{M}$; horizontal bar) did not alter the amplitude of OFQ/N-activated currents (300 $\mathrm{nM}$; arrowheads).

were not significantly different from the effects of vehicle administered at the same four circadian times (ANOVA, $p>0.05$ ).

In rodents maintained under constant darkness, a single, brief exposure to light during the latter half of the subjective night results in a permanent phase advance of the circadian activity rhythm (DeCoursey, 1964; Rea et al., 1993). Certain SCN neurotransmitters have been shown to modify this response to light, including serotonin and neuropeptide Y (Rea et al., 1993, 1994; Weber et al., 1995a,b). In the present study, light exposure after vehicle injection at CT19 resulted in a phase advance of $62 \pm 5$ min (Fig. 4). The injection of $<5$ pmol of OFQ/ $\mathrm{N}$ before light exposure failed to alter the magnitude of the light-induced phase advance [0.1 pmol, $61.8 \pm 6.8 \mathrm{~min}(n=6) ; 0.5$ pmol, $70.3 \pm 8.3$ $\min (n=7)$; and $1.0 \mathrm{pmol}, 57.0 \pm 7.3 \mathrm{~min}(n=5) ;$ ANOVA, $p<$ 0.96]. However, injection of $5.0 \mathrm{pmol}$ of OFQ/N resulted in a $39 \%$ reduction in the magnitude of the light-induced phase advance [39 $\pm 10 \min (n=7) ; p<0.05]$. A similar reduction in the phase advance was obtained with injection of $50 \mathrm{pmol}$ of OFQ/N [38 \pm $3 \min (n=4) ; p<0.05]$.

\section{Inhibition of NMDA receptor-mediated $\mathrm{Ca}^{2+}$ influx by OFQ/N}

An important component of light-induced phase shifts of the circadian clock is the activation of NMDA receptors by glutamate released from the RHT and an increase of intracellular $\mathrm{Ca}^{2+}$ (MacDermott et al., 1986; Ding et al., 1994). We therefore tested whether OFQ/N could modify the intracellular levels of $\mathrm{Ca}^{2+}$ in SCN neurons. NMDA $(100 \mu \mathrm{M})$ increased the intracellular $\mathrm{Ca}^{2+}$ levels in the SCN $16.3 \pm 2.7 \%$ (mean $\pm \mathrm{SE} ; n=4$; Fig. 5). Application of OFQ/N $(1 \mu \mathrm{M})$ alone produced a small decrease in intracellular $\mathrm{Ca}^{2+}(6.0 \pm 1.5 \%$, mean $\pm \mathrm{SE} ; n=4)$. However, after OFQ/N (1 $\mu \mathrm{M})$, the NMDA-induced increase in intracellular $\mathrm{Ca}^{2+}$ was reduced $40 \%(9.9 \pm 2.7 \%$, mean $\pm \mathrm{SEM} ; n=4)$. The NMDA response slowly returned to that of NMDA alone. In contrast, OFQ/N did not alter the NMDA-induced increase in intracellular $\mathrm{Ca}^{2+}$ in the anterior hypothalamic area [NMDA $(16.1 \pm 5.5 \%)$ vs OFQ/N and NMDA $(13.9 \pm 4.9 \%)]$. OFQ/N may therefore act to reduce the effects of light on the circadian clock by inhibiting the NMDA receptor-induced increase of intracellular $\mathrm{Ca}^{2+}$.

\section{DISCUSSION}

The data presented in this report demonstrate that (1) the $\mathrm{OFQ} / \mathrm{N}$ peptide and its receptor are present in the SCN, (2) $\mathrm{OFQ} / \mathrm{N}$ alters the activity of the majority of SCN neurons, and (3) $\mathrm{OFQ} / \mathrm{N}$ injected into the $\mathrm{SCN}$ region modulates the response of the circadian clock to photic stimuli (Figs. 1, 2, 4). These observations argue strongly for a role of $\mathrm{OFQ} / \mathrm{N}$ as a modulatory neuropeptide in the SCN. Furthermore, because OFQ/N is synthesized as part of a precursor protein that is not found in the $\mathrm{SCN}$, the ppOFQ/N must be synthesized by neurons in brain regions that project to and innervate the SCN. Additional research will be required to understand the physiological functions of $\mathrm{OFQ} / \mathrm{N}$ in the $\mathrm{SCN}$ and to describe the $\mathrm{OFQ} / \mathrm{N}$ projection pathways.

OFQ/N inhibited the light-induced phase shifts of the onset of wheel-running activity of Syrian hamsters (Fig. 4). In contrast, $\mathrm{OFQ} / \mathrm{N}$ did not directly phase shift the circadian clock. These data suggest that the signal transduction pathways, which are coupled to NOR, are not directly capable of modifying the timing of the circadian clock. Nocturnal light phase advances the circadian clock when applied during the latter portion of the subjective night (DeCoursey, 1964; Rea et al., 1993, 1994; Weber et al., 1995a,b). This phase advance is mediated by a rise of intracellular $\mathrm{Ca}^{2+}$ via activation of NMDA receptors by glutamate released from the RHT (MacDermott et al., 1986; Ding et al., 1994). Elevated intracellular $\mathrm{Ca}^{2+}$ activates nitric oxide synthase, re- 


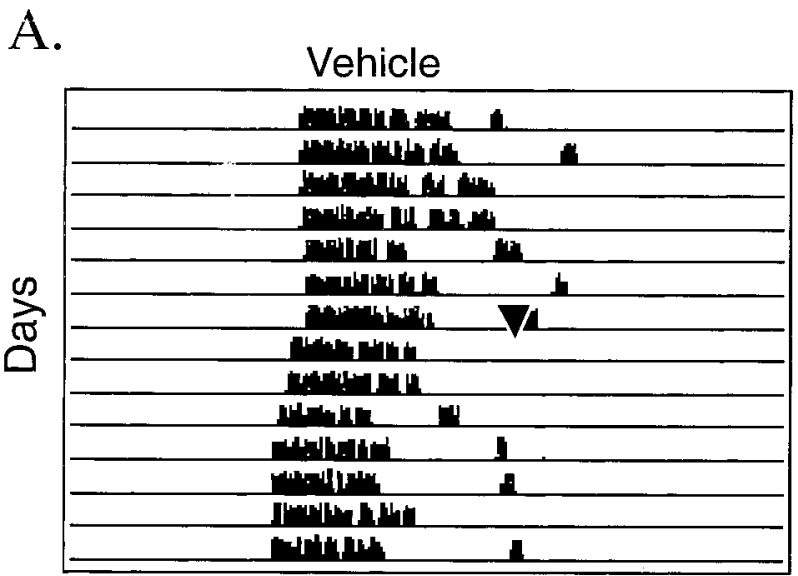

$5.0 \mathrm{pmol}$ OFQ

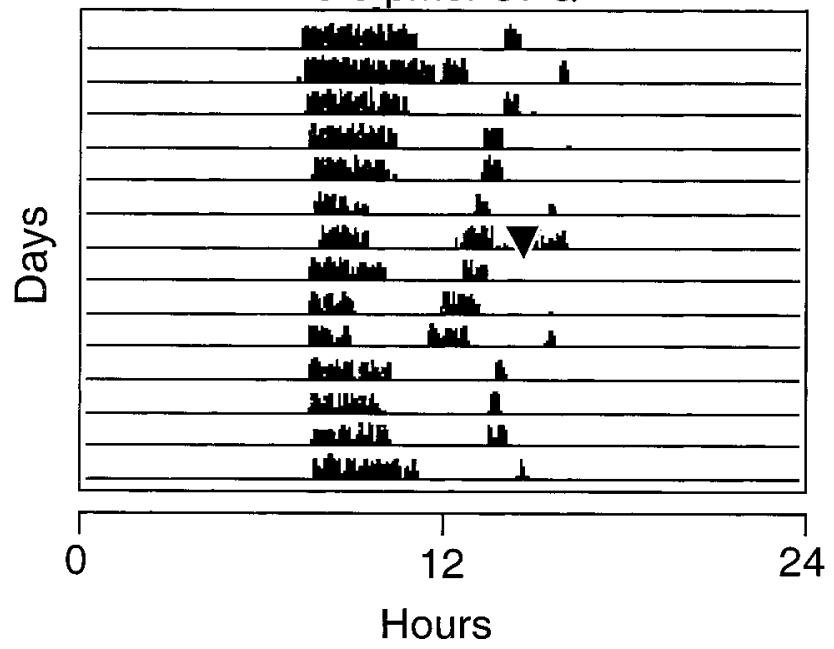

\section{$0.5 \mathrm{pmol} O F Q$}

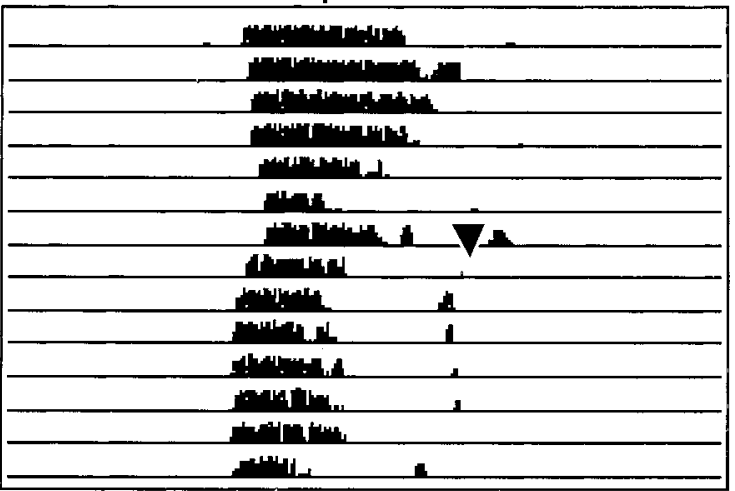

$50 \mathrm{pmol}$ OFQ
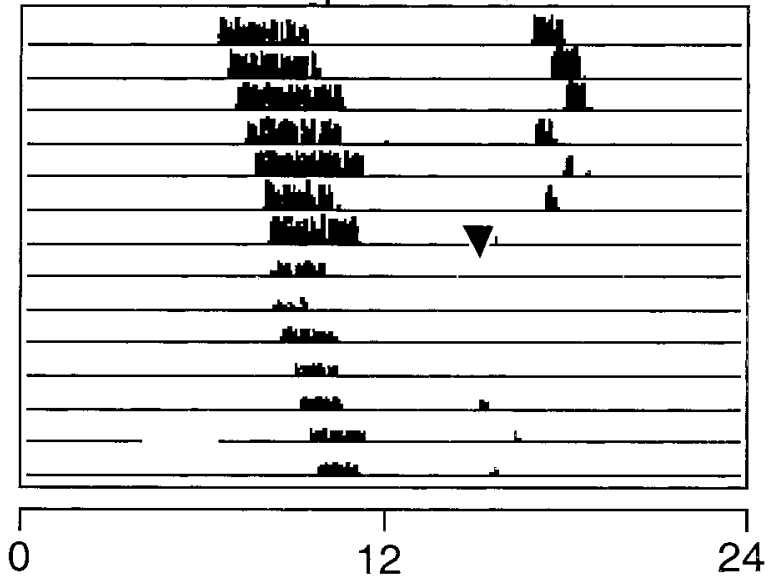

Hours

B.

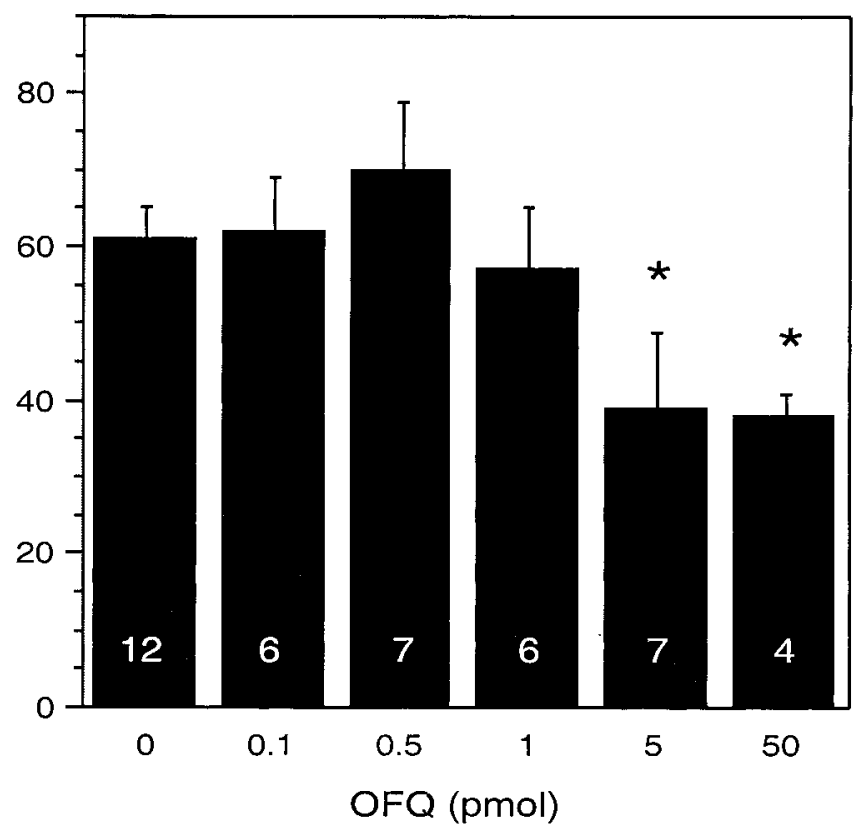

Figure 4. Effects of $\mathrm{OFQ} / \mathrm{N}$ on light-induced phase shifts. A, Actographs showing that injection of $\mathrm{OFQ} / \mathrm{N} 10 \mathrm{~min}$ before a $10 \mathrm{~min}$ light exposure at CT19 reduced the phase shift induced by the light pulses. $B$, Dose-dependent effect of local administration of OFQ/N on the light-induced phase shifts. Data represent the means $\pm \mathrm{SD}$, and the number of determinations are indicated within each bar. OFQ, Orphanin-FQ/nociceptin. 

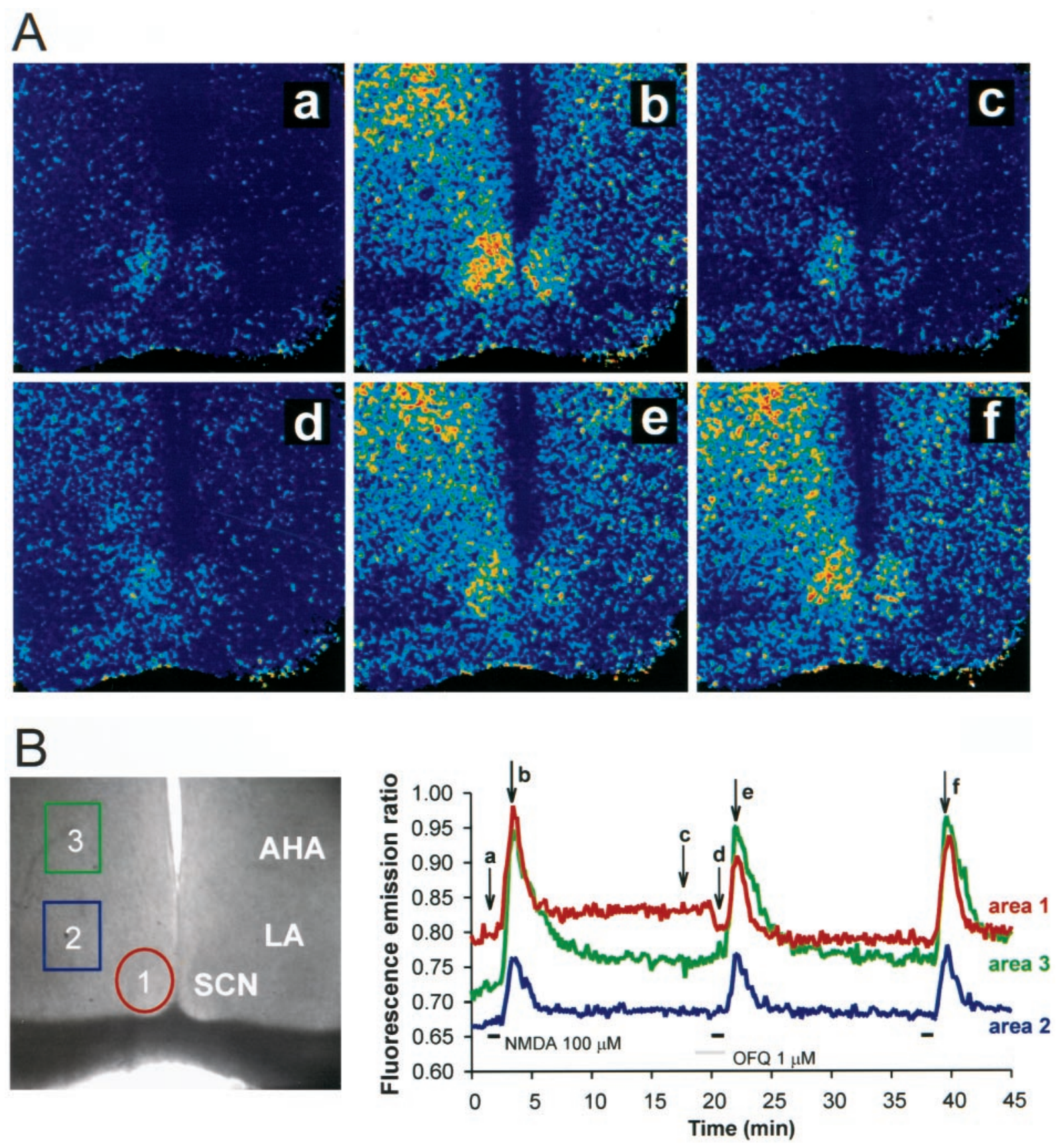

Figure 5. Effects of OFQ/N on intracellular $\mathrm{Ca}^{2+}$ and $N M D A$-activated increases in intracellular $\mathrm{Ca}^{2+}$. $A$, Pseudocolor ratio images of $N M D A$-evoked increases in intracellular $\mathrm{Ca}^{2+}$ concentration. The individual frames are control $(a), N M D A(100 \mu \mathrm{M} ; b)$, washout of $N M D A(c)$, application of OFQ/N $(1 \mu \mathrm{M} ; d), N M D A(100 \mu \mathrm{M} ; e)$, and the control NMDA response $(f) . B$, Normal illumination of an SCN slice shown with the regions of analysis outlined. The graph represents a continuous plot of the data; the analyzed areas (areas 1-3) correspond to the outlined areas on the left in $B$. The images shown in $A$ correspond to the letters on the graph in $B$. The images are taken once each 10 sec. Horizontal bars on the graph indicate $N M D A$ and OFQ/N application. $A H A$, Anterior hypothalamus; $L A$, lateral anterior hypothalamus; $O F Q$, orphanin-FQ/nociceptin; $S C N$, suprachiasmatic nucleus.

sulting in increased nitric oxide production (Ding et al., 1994). Nitric oxide synthesis and release are required for both light- and glutamate- induced phase shifts to occur (Ding et al., 1994; Weber et al., 1995a). Light-induced phase advances also require cGMPdependent protein kinase $\mathrm{G}$ activity, which is presumed to be increased as a consequence of the elevation of cGMP levels by nitric oxide (Ding et al., 1994, 1998; Weber et al., 1995a,b). Thus, inhibition of the increase of intracellular $\mathrm{Ca}^{2+}$ should attenuate the light-induced phase advance. In the present report, we show that, in addition to attenuating photic phase advances, OFQ/N dose-dependently inhibits the NMDA receptor-mediated increase in intracellular $\mathrm{Ca}^{2+}$ on SCN neurons by a mechanism that remains to be described (Fig. 5). Therefore, we propose that $\mathrm{OFQ} / \mathrm{N}$ acts as a negative modulator of RHT neurotransmission via inhibition of the rise of intracellular $\mathrm{Ca}^{2+}$ mediated by NMDA receptors on retinorecipient SCN neurons, resulting in an attenuation of photic phase adjustments of the circadian clock.

OFQ/N produced a maximum $39 \%$ reduction in the magnitude of the light-induced phase advance (Fig. 4). This effect of OFQ/N is in contrast with that of excitatory amino acid antagonists that 
have the ability, at proper concentrations, to block completely the light-induced phase shift (Rea et al., 1993). OFQ/N's inability to block completely the light-induced phase shift may be attributable in part to the fact that $\mathrm{OFQ} / \mathrm{N}$ was only injected into one side of the SCN. Bilateral activation of NORs in the SCN may be required for the complete block of the light-induced phase shift. A second possibility is that the mechanism of OFQ/N action is different from that of other neuromodulators and $\mathrm{OFQ} / \mathrm{N}$ does not have the ability to produce a complete block of the lightinduced phase shifts. This is consistent with the observation that OFQ/N only attenuated the NMDA-induced rise in intracellular $\mathrm{Ca}^{2+} 40 \%$ (Fig. 5).

SCN neurons are heterogeneous in their morphology, their afferent synapses, and their responses to neurotransmitters. The percentage of SCN neurons that responded to OFQ/N (88\%) was higher than has been observed for other neurotransmitters in the SCN. In our experience $39 \%$ of SCN neurons respond to melatonin, $28 \%$ respond to serotonin, and $35 \%$ respond to baclofen, percentages that are similar to those reported by others (Jiang et al., 1995a,b). For example, baclofen inhibited the single-unit discharges of $65 \%$ of SCN neurons sampled, while producing an outward current in only 35\% of neurons (Liou et al., 1990; Jiang et al., 1995a). Melatonin application generated an outward current in only $35 \%$ of cells and inhibited the firing of $39-100 \%$ of SCN neurons depending on the preparation and the time of day (Mason and Brooks, 1988; Shibata et al., 1989; Stehle et al., 1989). 5 -HT application activated an outward current in only $27 \%$ of cells and inhibited firing in only $49-56 \%$ of cells (Mason and Brooks, 1988; Meijer and Groos, 1988; Miller and Fuller, 1990). The fact that $88 \%$ of SCN neurons respond to OFQ/N makes it one of the most ubiquitous modulators of the activity of SCN neurons.

NOR mRNA is expressed and the OFQ/N peptide dosedependently activates outward currents in SCN neurons (Figs. 1-3). OFQ/N modulates the membrane conductance and activity of SCN neurons by activating a $\mathrm{K}^{+}$current that would hyperpolarize the membrane potential making the $\mathrm{SCN}$ neurons less excitable (Fig. 2). NORs are coupled to $\mathrm{G}_{\mathrm{i}}$-type $\mathrm{G}$-proteins and inhibit forskolin-stimulated adenylyl cyclases and voltage-gated $\mathrm{Ca}^{2+}$ channels via a pertussis toxin-sensitive mechanism (Meunier et al., 1995; Reinscheid et al., 1995). Further work will be needed to determine whether NORs on SCN neurons are coupled to similar effector systems. When expressed in Xenopus oocytes, NORs can couple to G-protein-activated $\mathrm{K}^{+}$channels consisting of Kir3.1 and Kir3.4 subunits (Matthes et al., 1996). Kir3 channels are G-protein-activated $\mathrm{K}^{+}$channels that are directly stimulated by $\beta \gamma$ G-protein subunits giving inwardly rectifying $\mathrm{K}^{+}$currents (Kofuji et al., 1995). OFQ/N has also been reported to activate an inwardly rectifying $\mathrm{K}^{+}$current in dorsal root ganglion, periaqueductal gray and arcuate neurons (Vaughan and Christie, 1996; Vaughan et al., 1997; Wagner et al., 1998). It is likely that the $\mathrm{K}^{+}$currents we observed are caused by NOR activation of G-protein-activated $\mathrm{K}^{+}$channels that are known to be present on SCN neurons (Karschin et al., 1994; Dißmann et al., 1996).

The OFQ/N peptide is present in the $\mathrm{SCN}$, whereas ppOFQ/N MRNA is not, suggesting that $\mathrm{ppOFQ} / \mathrm{N}$ is synthesized by neurons in brain regions that project to the SCN (Fig. $1 B-D$ ). The identity of the afferent projection pathway or pathways remains unknown. However, several brain regions are implicated as potential sources of the OFQ/N projection because of their neuroanatomical and functional relationships with the SCN. Entrain- ment of the circadian pacemaker is tightly regulated by environmental lighting cues that are conveyed to the SCN by both direct and indirect pathways. The intergeniculate leaflet (IGL) is a small region located between the dorsolateral geniculate and the ventrolateral geniculate that receives dense input from the retina and projects via the geniculohypothalamic tract to the SCN (Card and Moore, 1989). Lesioning the IGL reduces the rate of re-entrainment after phase advances or phase delays (Harrington and Rusak, 1986; Pickard et al., 1987). Four types of neurons exist within the IGL, and the two best-studied neurotransmitters found in some of these neurons are GABA and neuropeptide Y (Shinohara et al., 1993; Morin and Blanchard, 1995). There are also IGL neurons that express an additional peptidergic neuromodulator that remains to be identified (Card and Moore, 1989). The presence of ppOFQ/N mRNA in the VGL suggests that OFQ/N neurons may exist in the IGL. However, the resolution of the in situ hybridization studies was not sufficient to identify positively the IGL. The lateral septum, preoptic area, and median raphe are regions that also have dense staining for $\mathrm{ppOFQ} / \mathrm{N}$ mRNA and provide afferent projections to the SCN (Moga and Moore, 1997; Darland et al., 1998). Future experiments will be performed that will lesion these regions to determine whether OFQ/N levels in the SCN are decreased.

$\mathrm{OFQ} / \mathrm{N}$ was originally identified as the endogenous ligand for a receptor with homology to the classical opioid receptors. Because of this apparent evolutionary relatedness, most studies to date have focused on a role for the peptide and its receptor in nociception and feeding behavior (Mogil et al., 1996; Pomonis et al., 1996). The present data demonstrate that OFQ/N can modulate the activity of SCN neurons and that OFQ/N has important actions in brain regions other than those involved in nociception. NORs are located on neurons of the SCN, and their activation increases the membrane conductance by activation of a $\mathrm{K}^{+}$current (Fig. 2). In addition, injection of $\mathrm{OFQ} / \mathrm{N}$ into the $\mathrm{SCN}$ region inhibits photic phase advances of the circadian activity rhythm. These observations suggest that OFQ/N alters the activity of retinorecipient SCN neurons by activation of a $\mathrm{K}^{+}$current, resulting in hyperpolarization of the membrane potential and inhibition of the response of the postsynaptic neuron to lightactivated RHT neurotransmission. In addition, OFQ/N may act as a negative modulator of RHT neurotransmission via inhibition of the rise of intracellular $\mathrm{Ca}^{2+}$ mediated by NMDA receptors on retinorecipient SCN neurons, resulting in an attenuation of photic phase adjustments of the circadian clock. In conclusion, the heptadecapeptide $\mathrm{OFQ} / \mathrm{N}$ has direct actions on SCN neurons and may serve as a modulator of the phase-regulatory effects of light on the circadian clock.

\section{REFERENCES}

Akaike N, Harata N (1994) Nystatin perforated patch recording and its application to analysis of intracellular mechanisms. Jpn J Physiol 44:433-473.

Bunzow JR, Saez C, Mortrud M, Bouvier C, Williams JT, Low M, Grandy DK (1994) Molecular cloning and tissue distribution of a putative member of the rat opioid receptor gene family that is not $\mathrm{m}, \mathrm{d}$ or $\mathrm{k}$ opioid receptor type. FEBS Lett 347:284-288.

Card JP, Moore RY (1989) Organization of lateral geniculatehypothalamic connections in the rat. J Comp Neurol 284:135-147.

Darland T, Heinricher MM, Grandy DK (1998) Orphanin FQ/nociceptin: a role in pain and analgesia, but so much more. Trends Neurosci 21:215-221.

De Vries MJ, Nunes Cardozo B, Van der Want J, De Wolf A, Meijer JH (1993) Glutamate immunoreactivity in terminals of the retinohypothalamic tract of the brown Norwegian rat. Brain Res 612:231-237. 
DeCoursey PJ (1964) Function of a light response rhythm in hamsters. J Comp Physiol [A] 63:189-196.

Dißmann E, Wischmeyer E, Spauschus A, Pfeil D, Karschin C, Karschin A (1996) Functional expression and cellular mRNA localization of a $\mathrm{G}$ protein-activated $\mathrm{K}+$ inward rectifier isolated from rat brain. Biochem Biophys Res Commun 223:474-479.

Ding JM, Chen D, Weber ET, Faiman LE, Rea MA, Gillette MU (1994) Resetting the biological clock: mediation of nocturnal circadian shifts by glutamate and NO. Science 266:1713-1717.

Ding JM, Buchanan GF, Tischkau SA, Chen D, Kuriashkina L, Faiman LE, Alster JM, McPherson PS, Campbell KP, Gillette MU (1998) A neuronal ryanodine receptor mediates light-induced phase delays of the circadian clock. Nature 394:381-384.

Dodt H-U, Zieglgänsberger W (1990) Visualizing unstained neurons in living brain slices by infrared DIC-videomicroscopy. Brain Res 537:333-336.

Harrington ME, Rusak B (1986) Lesions of the thalamic intergeniculate leaflet alter hamster circadian rhythms. J Biol Rhythms 1:309-325.

Inouye S-IT (1996) Circadian rhythms of neuropeptides in the suprachiasmatic nucleus. In: Hypothalamic integration of circadian rhythms (Buijs RM, Kalsbeek A, Romijn HJ, Pennartz CMA, Mirmiran M, eds), pp 75-90. Amsterdam: Elsevier.

Jiang Z-G, Allen CN, North RA (1995a) Presynaptic inhibition by baclofen of retinohypothalamic excitatory synaptic transmission in rat suprachiasmatic nucleus. Neuroscience 64:813-819.

Jiang Z-G, Nelson CS, Allen CN (1995b) Melatonin activates an outward current and inhibits $\mathrm{Ih}$ in rat suprachiasmatic nucleus neurons. Brain Res 687:125-132.

Jiang Z-G, Yang Y-Q, Liu Z-P, Allen CN (1997) Membrane properties and synaptic inputs of suprachiasmatic nucleus neurons in rat brain slices. J Physiol (Lond) 499:141-159.

Karschin C, Schreibmayer W, Dascal N, Lester H, Davidson N, Karschin A (1994) Distribution and localization of $G$ protein-coupled inwardly rectifying $\mathrm{K}^{+}$channel in the rat. FEBS Lett 348:139-144.

Kim YI, Dudek FE (1991) Intracellular electrophysiological study of the suprachiasmatic nucleus neurons in rodents: excitatory synaptic mechanisms. J Physiol (Lond) 444:269-287.

Kofuji P, Davidson N, Lester HA (1995) Evidence that neuronal $\mathrm{G}$-protein-gated inwardly rectifying $\mathrm{K}^{+}$channels are activated by $\mathrm{G} \beta \gamma$ subunits and function as heteromultimers. Proc Natl Acad Sci USA 92:6542-6546.

Liou SY, Shibata S, Albers HE, Ueki S (1990) Effects of GABA and anxiolytics on the single unit discharge of suprachiasmatic neurons in rat hypothalamic slices. Brain Res Bull 25:103-107.

MacDermott AB, Mayer ML, Westbrook GL, Smith SJ, Barker JL (1986) NMDA-receptor activation increases cytoplasmic calcium concentration in cultured spinal cord neurones. Nature 321:519-522.

Mason R, Brooks A (1988) The electrophysiological effects of melatonin and a putative melatonin antagonist ( $N$-acetyltryptamine) on rat suprachiasmatic neurones in vitro. Neurosci Lett 95:296-301.

Matthes H, Seward EP, Kieffer B, North RA (1996) Functional selectivity of orphanin FQ for its receptor coexpressed with potassium channel subunits in Xenopus laevis oocytes. Mol Pharmacol 50:447-450.

Meijer JH, Groos GA (1988) Responsiveness of suprachiasmatic and ventral lateral geniculate neurons to serotonin and imipramine: a microiontophoretic study in normal and imipramine-treated rats. Brain Res Bull 20:89-96.

Meijer JH, Rietveld WJ (1989) Neurophysiology of the suprachiasmatic circadian pacemaker in rodents. Physiol Rev 69:671-707.

Meunier J-C, Mollereau C, Toll L, Suaudeau C, Moisand C, Alvinerie P, Butour J-L, Guillemot J-C, Ferrara P, Monsarrat B, Mazargull H, Vassart G, Parmentier M, Costentin J (1995) Isolation and structure of the endogenous agonist of opioid receptor-like $\mathrm{ORL}_{1}$ receptor. Nature 377:532-535.

Miller JD, Fuller CA (1990) The response of suprachiasmatic neurons of the rat hypothalamus to photic and serotonergic stimulation. Brain Res 515:155-162.

Moga MM, Moore RY (1997) Organization of neural inputs to the suprachiasmatic nucleus in the rat. J Comp Neurol 389:508-534.

Mogil JS, Grisel JF, Reinscheid RK, Civelli O, Belknap JK, Grandy DK (1996) Orphanin FQ is a functional anti-opioid peptide. Neuroscience 75:333-337.

Mollereau C, Parmetier M, Mailleux P, Butour JL, Moisand C, Chalon P, Caput D, Vassart G, Meunier JC (1994) ORL1, a novel member of the opioid receptor family. Cloning, functional expression, and localization. FEBS Lett 341:33-38.

Mollereau C, Simons M-J, Soularue P, Liners F, Vassart G, Meunier J-C, Parmentier M (1996) Structure, tissue distribution, and chromosomal localization of the prepronociceptin gene. Proc Natl Acad Sci USA 93:8666-8670.

Moore RY, Speh JC, Card JP (1995) The retinohypothalamic tract originates from a distinct subset of retinal ganglion cells. J Comp Neurol 352:351-366.

Morin LP (1994) The circadian visual system. Brain Res Rev 19:102-127.

Morin LP, Blanchard J (1995) Organization of the hamster intergeniculate leaflet: NPY and ENK projections to the suprachiasmatic nucleus, intergeniculate leaflet and posterior limitans nucleus. Vis Neurosci 12:57-67.

Nothacker H-P, Reinscheid RK, Mansour A, Henningsen RA, Ardati A, Monsma Jr FJ, Watson SJ, Civelli O (1996) Primary structure and tissue distribution of the orphanin FQ precursor. Proc Natl Acad Sci USA 93:8677-8682.

Pickard GE, Ralph MR, Menaker M (1987) The intergeniculate leaflet partially mediates effects of light on circadian rhythms. J Biol Rhythms 2:35-56.

Pomonis JD, Billington CJ, Levine AS (1996) Orphanin FQ, agonist of orphan opioid receptor $\mathrm{ORL}_{1}$, stimulates feeding in rats. NeuroReport 8:369-371.

Quigley DI, McDougall J, Darland T, Zhang G, Ronnekleiv OK, Grandy DK, Allen RG (1998) Orphanin FQ is the major OFQ ${ }^{1-17}$-containing peptide produced in the rodent and monkey hypothalamus. Peptides 19:133-139.

Rea MA, Buckley B, Lutton LM (1993) Local administration of EAA antagonists blocks light-induced phase shifts and c-fos expression in hamster SCN. Am J Physiol 254:R1191-R1198.

Rea MA, Glass JD, Colwell CS (1994) Serotonin modulates photic responses in the hamster suprachiasmatic nuclei. J Neurosci 14:3635-3642.

Reinscheid RK, Nothacker H-P, Bourson A, Ardati A, Henningsen RA, Bunzow JR, Grandy DK, Langen H, Monsma Jr FJ, Civelli O (1995) Orphanin FQ: a neuropeptide that activates an opioidlike G proteincoupled receptor. Science 270:792-794.

Shibata S, Cassone VM, Moore RY (1989) Effects of melatonin on neuronal activity in the rat suprachiasmatic nucleus in vitro. Neurosci Lett 97:140-144.

Shinohara K, Tominaga K, Fukuhara C, Otori Y, Inouye S-IT (1993) Processing of photic information within the intergeniculate leaflet of the lateral geniculate body: assessed by neuropeptide $\mathrm{Y}$ immunoreactivity in the suprachiasmatic nucleus of rats. Neuroscience 56:813-822

Shirakawa T, Moore RY (1994) Glutamate shifts the phase of the circadian neuronal firing rhythm in the rat suprachiasmatic nucleus in vitro. Neurosci Lett 178:47-50.

Stehle J, Vanecek J, Vollrath L (1989) Effects of melatonin on spontaneous electrical activity of neurons in rat suprachiasmatic nuclei: an in vitro iontophoretic study. J Neural Transm 78:173-177.

Van den Pol AN, Tsujimoto KL (1985) Neurotransmitters of the hypothalamic suprachiasmatic nucleus: immunocytochemical analysis of 25 neuronal antigens. Neuroscience 15:1049-1086.

Vaughan CW, Christie MJ (1996) Increase by the $\mathrm{ORL}_{1}$ receptor (opioid receptor-like ${ }_{1}$ ) ligand, nociceptin, of inwardly rectifying $\mathrm{K}$ conductance in dorsal raphe nucleus neurones. Br J Pharmacol 117:1609-1611.

Vaughan CW, Ingram SL, Christie MJ (1997) Actions of the ORL receptor ligand nociceptin on membrane properties of rat periaqueductal gray neurons in vitro. J Neurosci 17:996-1003.

Wagner EJ, Rønnekleiv OK, Grandy DK, Kelly MJ (1998) The peptide orphanin FQ inhibits $\beta$-endorphin neurons and neurosecretory cells in the hypothalamic arcuate nucleus by activating an inwardly-rectifying $\mathrm{K}^{+}$conductance. Neuroendocrinology 67:73-82.

Weber ET, Gannon RL, Michel AM, Gillette MU, Rea MA (1995a) Nitric oxide synthase inhibitor blocks light-induced phase shifts of the circadian activity rhythm, but not $c$-fos expression in the suprachiasmatic nucleus of the Syrian hamster. Brain Res 692:137-142.

Weber ET, Gannon RL, Rea MA (1995b) cGMP-dependent protein kinase inhibitor blocks light-induced phase advances of circadian rhythms in vivo. Neurosci Lett 197:227-230.

Xu IS, Wiesenfeld-Hallin Z, Xu X-J (1998) [Phe ${ }^{1 y}(\mathrm{CH}-\mathrm{NH}) \mathrm{Gly}^{2}$ ]-nociceptin-1(1-13) $\mathrm{NH}_{2}$, a proposed antagonist of the nociceptin recepntor, is a potent and stable agonist in the rat spinal cord. Neurosci Lett 249:127-130. 